\title{
Update of the japanese national registry of pediatric rheumatic disease
}

\author{
Ken-Ichi Yamagchi ${ }^{1 *}$, Yasuhito Nerome ${ }^{2}$, Tomoyuki Imagawa ${ }^{3}$, \\ Committee of PRICURE registry in Pediatric Rheumatology Association of Japan (PRAJ) \\ From 21st European Pediatric Rheumatology (PReS) Congress \\ Belgrade, Serbia. 17-21 September 2014
}

\section{Introduction}

We, Pediatric Rheumatology Association of Japan (PRAJ), have set up new online national registry of pediatric rheumatic diseases.

\section{Objectives}

We report the first several months of enrollment to PRICURE (Pediatric Rheumatology International Collaboration Unit Registry).

\section{Methods}

Professor Shuji TAKEI, the former chairman of PRAJ had ordered his working group to set up a new registry system in 2012. Ethical issues about the registry in which we use clinical information were discussed by ethics committee of PRAJ and it had been approved in 2013. We started to collected basic information (e.g. name of rheumatic disease, age of onset, sex, clinical course) and further information (e.g. clinical symptoms, laboratory examination abnormalities, radiological examination abnormalities, treatment, complications) by web-based way in spring 2014.

\section{Results}

In the end of May 2014, 394 cases had been registered in the PRICURE. The number of cases of each diseases are as follow, Juvenile Idiopathic Arthritis 174, Systemic Lupus Erythematosus 65, Juvenile Dermatomyositis 43, Sjogren syndrome 14, Mixed Connective Tissue Disease 29, Systemic Sclerosis 12, Behcet's Disease 8, Vasculitis 16, Autoinflammatory Syndromes 1, Fibromyalgia 38.

\section{Conclusion}

We hope that this registry contribute to the development of clinical research in the field of pediatric rheumatology.

\section{Disclosure of interest}

None declared.

\begin{abstract}
Authors' details
${ }^{1}$ Immuno-Rheumatology Center, St. Luke's International Hospital, Tokyo, Japan. ${ }^{2}$ Pediatrics, Kagoshima University, Kagoshima, Japan. ${ }^{3}$ Dpartment of Immunology and Infectious Diseases, Kanagawa Children's Medical Center, Yokohama, Japan.
\end{abstract}

Published: 17 September 2014

doi:10.1186/1546-0096-12-S1-P294

Cite this article as: Yamagchi et al:: Update of the japanese national registry of pediatric rheumatic disease. Pediatric Rheumatology 2014 12(Suppl 1):P294
${ }^{1}$ Immuno-Rheumatology Center, St. Luke's International Hospital, Tokyo, Japan

Full list of author information is available at the end of the article
Submit your next manuscript to BioMed Central and take full advantage of:

- Convenient online submission

- Thorough peer review

- No space constraints or color figure charges

- Immediate publication on acceptance

- Inclusion in PubMed, CAS, Scopus and Google Scholar

- Research which is freely available for redistribution

Submit your manuscript at www.biomedcentral.com/submit
() Biomed Central 